\title{
Paideusis
}

\section{Reflection and Practices: Teacher Education and the Teaching Profession (John Wilson)}

\section{Murray Elliott}

Volume 8, Number 2, 1995

URI: https://id.erudit.org/iderudit/1073256ar

DOI: https://doi.org/10.7202/1073256ar

See table of contents

Publisher(s)

Canadian Philosophy of Education Society

ISSN

0838-4517 (print)

1916-0348 (digital)

Explore this journal

Cite this document

Elliott, M. (1995). Reflection and Practices: Teacher Education and the Teaching Profession (John Wilson). Paideusis, 8(2), 33-42.

https://doi.org/10.7202/1073256ar viewed online.

https://apropos.erudit.org/en/users/policy-on-use/ 


\section{Review Article}

John Wilson (1993). Reflection and Practice: Teacher Education and the Teaching Profession. London, ON: The Althouse Press.

\section{Reviewed by Murray Elliott, University of British Columbia}

Reading John Wilson's latest book has been something of a love-hate experience, in places stimulating and rewarding and in others, perplexing and frustrating. At some times, I have wanted to say "Wilson has it exactly right"; at others, "He's got it all wrong"; at still others, "What's he really up to?" This mixed reaction has perturbed me from beginning to end over more than one reading, and that is perhaps one of the strongest reasons for urging others in the "ed. biz." (as Wilson refers to the overall enterprise of education, encompassing schooling and teacher education) to read and assess the book for themselves. In what follows, I shall attempt to elucidate and explain my conflicting reactions to Wilson's book.

\section{A profession in crisis}

Wilson writes with the same passion that has sustained him throughout his career, initially in school teaching and later in teacher education, and in the text of more than thirty books. Wilson's style continues as lively and as provocative as ever, though at times it is needlessly complex because of his propensity to scatter the main text with parenthetical sub-text commentaries, asides, and parallel ideas. As always, Wilson's own sense of urgency is infectious as ideas tumble from his pen and the reader is pulled into the vortex of a lively mind racing to give insights expression and support.

In Reflection and Practice, Wilson's passion is focused on the teaching profession and the preparation of teachers. Teaching is, he believes, at a crisis (p. 63), not because technological advances might render teachers superfluous, not because teachers are without potential for exercising influence over individuals or society, and not because the rewards of teaching make it incapable of attracting sufficient recruits. Such common claims as these do not enter Wilson's thinking. Teaching is at a crisis, he maintains, because of the widespread "de-intellectualization" of the teaching profession; indeed, he argues, so far advanced is this de-intellectualizing that it is questionable whether teaching can in any significant sense be properly called a profession. Of particular concern is the increasing de-intellectualization of teacher education, for from this source the entire "profession" can in time be similarly de-intel- lectualized. Because of this potential, the key to reform lies here as well.

Wilson identifies a number of "symptoms of de-intellectualization in the educational world"' (p. 63). According to him,

a basic cause of, or at least correlation with, the alleged de-intellectualization ... is ... the removal of deference to intellectual authority and indeed ... to authority in general. By and large, it is clear that pupils at school, teachers in training, practising teachers, educational advisers, the inspectorate, local education authorities, civil servants and indeed almost all potent groups in the world of education do not look up or defer to, admire and seek to emulate, or in general take their cue from intellectuals .... (p. 65) 
Particularly pernicious is the fact that educational studies disciplines, at least as studies taken seriously and pursued systematically and with appropriate respect for the standards of the disciplines themselves, are being de-emphasized within, if not eliminated from, pre-service teacher education programs. Such studies are being replaced by shallow treatments of fashionable topics and by longer periods of school experience, but topics and experience devoid of clearly articulated intellectual structures, objectives, or requirements.

Wilson urges a return to a more intellectually-oriented teacher preparation program, the core of which would be "sophisticated reflection," or the sustained systematic study of disciplines underlying the practice of education. Such studies would be taught by " ... intellectuals in the disciplines who are as well qualified as ... those in 'pure' philosophy, psychology, etc." (p. 83). These studies would constitute 23 weeks of a full-time, three-semester, post-degree teacher education program. To this, Wilson would add two other components. The first is "practical experience of schools" consisting of a total of nine weeks of one- or two-week experiences of as many types of schools as possible, both independent and public, as well as schools serving different types of students (e.g., students with different ethnic, social, or learning characteristics). The final component would be a fortnight focusing on "techniques, tools and hardware," during which prospective teachers would gain skill in using a wide variety of the latest technology and learning aids. This pre-service program would be followed by one or two probationary years during which new teachers would prove their ability to teach effectively over a full year. Only after success is thus demonstrated would new teachers be regarded as fully qualified.

Notably missing from Wilson's proposed program would be universitybased "methods" studies, both general teaching methods, and subject-related methods studies. Candidates would acquire content-knowledge of teaching subjects in their pre-admission first-degree studies, and would learn details of particular teaching methods and approaches during their post-preparation probationary year(s). Wilson's grounds for excluding methods studies from the university program are that either such studies belong within the category of "practical experience" and are, therefore, better handled in schools by practising teachers or else they fit properly within the category of "sophisticated reflection" and should, therefore, be done "by people adequately competent in the required abilities (roughly in philosophy and psychology)" (p. 150). Curriculum design and the selection and sequencing of knowledge for instructional purposes would not find a place in Wilson's teacher education curriculum other than as these topics might be addressed during the systematic study of one or more academic disciplines during the 23 weeks of sophisticated reflection or as they might come up during the probationary year(s). About the probationary period Wilson says very little other than that during and at the close of this period would be the final assessment of new teachers' competence (p. 148).

It is impossible to capture in a précis the full details of Wilson's basic position, let alone of the structure or the nuances of arguments by which he supports his diagnosis and proposals. But this summary will, perhaps, be a sufficient sketch of the general theme of the book and of the kind of position Wilson advances. It will suffice also as a base from which to initiate questions about the adequacy of his diagnosis of the current state of crisis in the "ed. biz." and from which to assess the appropriateness of his recommendations. 


\section{De-intellectualization}

There is much in Wilson's presentation with which most readers of this journal will be sympathetic. Most readers will appreciate the complexities of fundamental issues concerning educational provision and practice and will understandably resonate to Wilson's insistence on ensuring that programs of initial teacher education include scope for the philosophical complexities of these issues to be explored with sufficient rigour that new teachers have both breadth and depth of understanding of them. Moreover, although like Wilson most philosophers of education will recognize in themselves a preference for philosophical studies for prospective teachers, like him we recognize also the importance of other educational studies disciplines being included within teacher preparation-some or all of educational psychology, sociology of education, history of education, anthropology of education, and comparative education. Some will argue for the inclusion, as well, of studies of economics and politics of education.

Many, however, will be more cautious in joining Wilson in the further claim that such studies should be pursued either in the relevant departments outside the faculty or department of education. We may be cautious because of a concern that, in many university departments, preferred teaching assignments include courses taken by graduate students and by advanced honours or majors undergraduates specializing in the discipline. Of lower priority are service courses for students in professional faculties who are required to take some studies in the discipline but whose total program structure and whose professional interests virtually preclude their considering or qualifying for graduate studies in that discipline. Moreover, a combination of the interests and experience of faculty members and the provisions for university personnel decisions, including the expectation of publication in the discipline's preferred journals, ensures that junior and untenured members teaching service courses not spend too much energy relating their discipline to professional issues or publishing in applied or professionally-oriented journals. Yet, if the basic disciplines, such as philosophy and psychology, are to deliver on their potential for illuminating professional practice, energy must be expended in interpreting and applying theoretical material of the disciplines to concerns of practice.

At the risk of invoking an ad hominem argument, I want to cite the work of Wilson himself as an example of just what I mean here. His work over many years, especially that concerned with moral education, has been immensely helpful to both prospective and practising teachers. Clearly, part of what has made it effective has been Wilson's familiarity with recent analytic work in philosophy, especially in ethics. Equally important, however, has been his ability to relate such philosophical work to classroom conditions. That ability is partly a result of his intimate knowledge of schools, curricula, and classroom practices-knowledge which he has gained through years of involvement in teaching and teacher education and knowledge which his philosophical colleagues not so involved are less likely to have.

This is not to deny that the work of philosophers working primarily or exclusively outside departments of education can be of inspiration and assistance in clarifying and even resolving issues of professional practice. On the 
contrary, the insights of many philosophers have enormous potential for illuminating educational issues and problems, even though their reflections may have proceeded outside this specific context. In ethics, for example, we have much to learn from people such as Alasdair MacIntyre and Charles Taylor (to name but two philosophers whose work I am currently finding particularly helpful), but it is doubtful that these philosophers have either the interest or the specific knowledge of schools and schooling to produce the detailed and illuminating analyses on moral education that John Wilson has developed. To expect them to do so would divert their attention from other important contributions. The general philosophical problems and the problems of educational theory are both so vast, so complex, and so interrelated that there is more than enough work for both general philosophers and philosophers of education, without trying to collapse both tasks onto the same overloaded individuals.

As I have noted earlier, Wilson is passionately concerned about the deintellectualization of education generally and, in particular, about the deintellectualization of teacher education. Early in the book, he presents a list of ten "symptoms" of this de-intellectualization. It is unfortunate, however, that in this section he presents neither evidence that those listed, in fact, prevail nor argument that, if they did, they would necessarily constitute "deintellectualization." Consider, for example,

the comparative absence of high-quality intellectuals in education generally (a check on the number of people with first-class degrees in reputable subjects would be interesting). (p. 64)

Later in the book, he revisits this point, again without evidence,

Not many schools attract first-rate people to become teachers, a fact too well-known to need comment here. (p. 160)

and extends it to encompass faculty members in "institutions of teacher education,"

How many of us have ever held, or could ever hold, a tenured position in any university department not concerned with education? How many of us have first-class degrees? How many have published anything worthy of respect outside the educational world?... The fact is that we are seen (and not only by scholars in the "pure" disciplines at universities) as third-rate, not serious, sometimes even as ridiculous. (p. 160)

Two pages further, still without evidence or argument, the "we are seen as" qualifier is dropped and Wilson declares more categorically that "... the system [of teacher education] is largely staffed by the third-rate ... " (p. 162).

I would not deny that there are some third-rate faculty members doing some third-rate work in faculties and departments of education, just as there probably are some third-rate faculty members doing some third-rate work in other university departments. University personnel procedures such as those referred to by Wilson (p. 162) provide latitude for varying qualities and quantities of creative output, certainly over the short-run and, sometimes, over the long-run as well. Creative output is difficult, if not impossible, to guarantee.

Wilson wants, however, to make a much stronger claim than I am willing to concede without argument. He wants to claim that the work of faculty members in faculties or departments of education is almost uniformly third-rate and, although he is less specific about other sectors of universities, it is quite 
clear that he believes the standard in the education units to be among the lowest. There is nothing to suggest that he regards the work of colleagues in the philosophy of education as much better than third-rate, for his approving citations seem to be restricted to work by Richard Peters, Paul Hirst, and-of course-John Wilson. I say "seem to be" because Wilson does not provide the reader with an index, and that makes it difficult to be sure one has noted every relevant reference in the text.

As examples of Wilson's assumption that a particular symptom, assuming it does prevail, constitutes de-intellectualization, consider the following two points in his list:

- the increased opposition to specialization and

- the strong trend towards politicization and ideologization, in particular the current dislike of "elitism" (p. 64).

Neither of these points is, as far as I can see, either obviously or necessarily an indicator of de-intellectualization. It could well be argued, for example, that a curriculum which requires people to master several fields of study is more intellectually demanding than a curriculum which allows people to specialize in a single field. Joint degrees, especially joint honours degrees, have frequently been regarded as more intellectually demanding than those in which people specialize in a single discipline. What needs to be considered is the level of intellectual demand built into the curriculum, however broad or however specialized that curriculum is. Similarly, whether elitism is a symptom of intellectual rigour or of de-intellectualization depends on the nature and basis of the elitism. Wilson will surely recognize that a century or so ago in certain older universities the height of elitism could well have coincided with their intellectual low-point to the degree that elitism may have been based on such factors as "breeding," wealth, and prior school connection rather than on intellectual achievement prior to or during university attendance.

I do not deny that we may be both witnesses and parties to some form of de-intellectualization in the "ed. biz." Wilson has claimed this to be so, but he has not shown it to be the case. Since it is he who is advancing the thesis, and since this is a central factual claim within his overall thesis, the onus is on him to make a coherent and convincing case for his claim. Simply affirming it, with whatever level of passion, is not enough. Nor is downgrading his colleagues in education departments because of their lack of significant publications in other fields any more relevant to such an argument than would be castigating scholars in physics or classics for their lack of important publications outside their fields of expertise. Wilson needs to pay much greater attention to the criteria of relevance and adequacy of evidence for factual claims if his overall argument is to be sound.

Wilson also needs, I think, to pay more attention to signs of hope within the teaching profession generally, and he needs to be more cautious about overemphasizing, and perhaps over-generalizing from, particular signs of weakness. For many are the signs of hope. At the level of personal experience, the more contact I have with classroom teachers and with those in other positions of professional responsibility, the more I recognize the dedication of inquiring and compassionate individuals, sometimes in an environment that is not particularly supportive of them. But evidence for high intellectual standards in the teaching 
profession is not only impressionistic. Although in times past not all teachers could justly claim a high level of scholarship, there have been significant changes in recent years. During the 1980s and the early 1990s, Canadian faculties of education have reported as many as ten qualified applicants for each position in their programs. Competition for admission has been so keen that frequently only those with first-class or upper-second-class degrees are admitted. Some universities have noted the academic requirements for admission to the elementary teaching program exceeding those for admission to other post-degree professional programs, such as law and medicine, that have traditionally been highly selective. ${ }^{1}$

I do not wish to fall into the trap of judging the quality of teachers solely on their standing in first-degree courses. My intention is rather to note that on the ground Wilson stakes out, the evidence-at least in Canada-is not entirely as he presumes. Yet, there are numerous indications in the book that he intends his thesis to apply to Canada, the United States, and the United Kingdom.

\section{Methods studies and school experience}

It is in the context of his views on de-intellectualization that we can understand Wilson's exclusion of method studies from the university portion of his proposed teacher preparation program. In my view, he correctly sees the need for different disciplinary contributions to what he calls method studies and what I would prefer to call studies in curriculum and instruction. Such studies encompass explorations into how a subject is to be conceptualized, both in general and with respect to different features of students' development; they include studies of the principles of selecting and sequencing subject-content for different types (age, gender, cultural background, developmental stage, abilitylevel, and so on.) of students; and they include studies of methods and strategies for presenting such material effectively to the diversity of learners in classrooms. Wilson, I think, has difficulty with the notion of an interdisciplinary subject, and believes that, like fostering subject integration or opposing subject specialization, as he earlier claimed, interdisciplinary studies necessarily involve de-intellectualization. As noted earlier, that is a matter on which he and I probably disagree in the end, and a claim which, in any case, he has failed to argue convincingly here.

Applying his position to the question of method studies, it is not surprising that after he has pared off from what I see as a complex interdisciplinary field all aspects that could connect with the particular educational disciplines (such as philosophy of education, and educational psychology), he finds little remaining content worthy of inclusion in a university syllabus. The practical question which must be asked, however, is whether student teachers are likely to be aided more in their pre-service professional development by studying matters related to curriculum and instruction in a potentially disconnected way under tutelage of several different disciplinary experts or in an integrated interdisciplinary approach organized in the context of their particular teaching subject(s). Of course, there is no reason why it need be one or other of these exclusively, but that is something which would depend on the degree of "fraternity of enquiry," to use his term, (p. 109) that exists in the particular teacher education institution. 
A further question which must be asked in this connection is whether Wilson has a sufficiently encompassing concept of method to discuss teaching methods as these are currently conceived and explored in the educational literature. On this, I have serious doubts. He is correct, I believe, in pointing to connections between method and content. For example, approaches to teaching such subjects as chemistry and physical education that do not pay sufficient attention to questions of safety are inadequate because of the nature of personal risk derived from what these studies are. But Wilson risks reducing method to content, with very little residue, other than some low-level skills which are hardly worthy of either mention or nurture. Other than what he refers to as "marginal cases," arguments about method "are really disguised arguments about content" (p. 90). Once you have clearly described the content to be taught, there is little of a methodological sort at issue:

If under "French" we have our eye on communication with present-day Frenchmen, we are more or less obliged to turn to certain methods (the "direct method," or farming children out to French families) and to eschew others (lengthy study of Ronsard or the defective verb "échoir"). (p. 90)

Such examples as Wilson gives exemplify a very coarse and simplistic conception of teaching methods as "how to teach such-and-such a subject" (p. 89) or else (as in the final parentheses in the preceding quotation) to be more concerned with what content to teach than with what methods to use in teaching it. Although some of the literature on teaching methods (for example, some of the process/product research or some of the research on direct instruction) may not be conceptually complex, other segments of this literature involve much more sophisticated reflection and analysis than exemplified by Wilson's examples "use the direct method," "make children learn tables by heart," or "teach grammar and syntax" (p. 90). It is hard to see how, with such an understanding of what teaching methods are, he could come to grips with the methodological aspects of the work of, for example, Egan, in his exploration of the use of story in teaching. 2

Having eliminated studies of teaching methods from his proposed teacher preparation program, Wilson removes teaching practice as well. This follows quite logically, for without benefit of methods studies it is not clear what students would be practising during teaching practice. Some school experience would remain within the program he outlines, but school experience which functions more as a setting for inquiry about schools than as a setting within which to practise methods, approaches, skills, and strategies and within which to improve professional competence. It is important, Wilson says, " . . . for the intending teachers to have some experience of as wide a variety of schools and other educational institutions as possible ...." The value of this experience is that it " . . will both free their minds from the parochialism which at present makes sophisticated reflection on education very difficult, and enable them to find their proper place within the very wide world of educational practice" (p. 150). Nor is improving classroom competence a matter to be delayed until the probationary year(s). For, although Wilson does not give much detail about what constitutes the probationary period, such comments as he makes suggest that it is a time for assessing probationers' classroom competence, not a time for aiding them in acquiring or improving it.

8(2), (Spring) 1995 
Two things need to be said about this proposal. First, at a very practical level, it is entirely unrealistic from the perspective of both students teachers and school personnel. Student teachers' highest priority in visiting schools is to learn to teach-to try their hand at teaching and to do this until they can do it well. In order to improve their own competence and to gain confidence, they need significant continuity of experience with a group of learners. Student teachers simply would not tolerate a program that required them to change schools every week or two. Nor, I fear, would school teachers and administrators be willing to invest the time and energy in setting up a rotational program of school experiences such as Wilson describes, knowing that the student teachers would be leaving before having time to make significant contributions to the school or the learners.

The second point goes deeper and relates to Wilson's understanding of teaching practice and, more generally, his understanding of the practice of teaching. Apart from the knowledge and understanding gained in university courses, and apart from a range of important personal qualities, teaching is largely a matter of low-level skills, skills that involve very little intellectual content (pp. 140-142). Wilson sees potential for intellectual challenge in the sophisticated reflections undertaken at a university. He does not, however, seem to see learning to improve one's own instructional practice as an intellectual endeavour. It is not clear from the book exactly what Wilson understands actual professional practice to consist of, but it seems clear that he does not conceive of it as having the intimate connection with intellectual reflection which Donald Schön ${ }^{3}$ has argued -that is, as "reflection-in-action," as action which incorporates intelligence, in contrast to "reflection-about-action" which is separated in time and/or space from the actual locus of action.

This is not the place to critique or defend in detail Schön's account of professional practice either in general or in relation to teaching; it is cited as an example of an account of professional practice which contrasts sharply with the one Wilson develops. The advantage of such an account is that it takes seriously, in a way in which Wilson's does not, a beginning professional's own developing professional competence and provides an intellectual entry to helping people acquire and improve his or her level of competence. Without some such account which takes seriously the development of professional competence and without some account which attempts to ground such competence in a theory of action or behaviour, and ultimately in a philosophy of mind (and a theory grounded in a behaviourist account of 'mind' will have its own possibilities), one will face Wilson's difficulty of having little that is significant to say about what teaching practice is and how professional competence is to be increased. Wilson began with a deep concern about the de-intellectualization of the teaching profession. He has attempted to outline a proposal for teacher education whereby this de-intellectualization could be reversed. I fear, however, that his account only aggravates the condition he set out to ameliorate. He has outlined a program wherein the intellectual is lodged firmly in the university, severed from the actual practice of teaching which on his account excludes (other than in the content taught) scope for significant intellectual activity. 


\section{Concluding remarks}

Lest I leave the reader with an unfairly negative assessment of Wilson's book, let me in conclusion draw attention to three of its many important strengths.

The first is an insightful and helpful chapter on "The Qualities of an Educator." He notes that, regrettably, "so little is written about this topic that is not superficial and ad hoc" (p. 111). His work is intended to-and in my assessment, does-help to rectify this deficiency. In his treatment, he wisely avoids detailed check-lists of "skills" or "behaviours" masquerading as qualities, and attempts to get at the underlying personal virtues, understood not in a contemporary moralistic manner but more in the classical sense of arete. Consistent with the thrust of the book as outlined above, Wilson argues for such intellectual virtues as knowledge, judgment, and wisdom and for certain related values, dispositions, and propensities. Wilson recognizes a place for particular social and other skills, but argues that more important than the skills themselves are relevant judgment- "knowing when to use these skills"-and an appropriate will_c"wanting (or not wanting) to use them" (p. 124). Wilson's analysis here is careful, sensitive, and clear. There is much in this section that would be helpful to student teachers as they are encouraged to reflect about and to formulate an appropriately comprehensive conception of their professional role and responsibility.

The second strength I wish to highlight is Wilson's carefully-argued critique of relativism, though I must say that the chapter in which this occurs is one of my love-hate sections of the book. Relativism he sees as a prevalent and "immensely powerful" position in contemporary education. Wilson's philosophical analysis and criticism in this chapter are clear and, to me, persuasive. He extends his analysis beyond the strictly philosophical to encompass interesting social science considerations as well: "Relativism," Wilson suggests, "is at root a kind of despair, a form or symptom of autism produced by loneliness and lack of communication," and this leads him to recommend involving students in co-operative learning, or as he refers to it "the fraternity of enquiry" (p. 109). Thus far, his work has much potential for student teachers as they review the issue of relativism in relation to their own teaching subject and the methods and approaches they will use in presenting their subject.

I remain unconvinced, however, that his arguments in this chapter on "Method and Relativism" support Wilson in his basic claim that teacher education should include no university method studies. He seems to think that methods instructors are particularly prone to epistemic relativism, that in view of the philosophical arguments he has presented such relativism constitutes further de-intellectualization, and that relativism ultimately undermines reason and renders education impossible (p. 109). Like Wilson, I have difficulty in incorporating relativism into my own thinking, but $I$ also have great difficulty in seeing why methods instructors should be particularly prone to adopt such a position. My own experience is that many of them have such a strong commitment to, and enthusiasm for, their subject that they have difficulty understanding how anyone could contemplate a world without it. If anything, such commitment is stronger than might be warranted by philosophical and sociological meta-analyses of traditional forms of academic inquiry, especially those contemporary meta-analyses that question the foundationalist presuppositions of scien- 
tific (and other forms of) inquiry. Moreover, as Richard Rorty has reminded us, relativists are more easily thought to exist than actually identified and we must be cautious about ascribing such a position to anyone:

"Relativism" is the view that every belief on a certain topic, or perhaps about any topic, is as good as every other. No one holds this view. Except for the occasional co-operative freshman, one cannot find anybody who says that two incompatible opinions on an important topic are equally good. ${ }^{4}$

Finally, the theme which Wilson opens for us in this book is one that is common across several professions, though no less important because of that commonality. Programs of medical education and legal education no less than those of teacher education are challenged to discover, rediscover, and implement an appropriate balance in both initial and continuing professional education between the reflective and the practical-between fundamental scholarship in relevant academic disciplines and realistic experience in concrete professional situations. It seems to be a feature of many such programs that in different times and/or places, the balance shifts too much in one direction or the other.

It is Wilson's view that in teacher education, programs are currently very much out of balance, and with passion and erudition he has called us to right that imbalance. As he affirms in his conclusion, whether he is correct on all points advanced is less important than that those engaged in teacher education take the matters seriously and work towards better solutions. For his stimulation on this project, as for his own contributions to it, we are in his debt.

\section{Notes}

${ }^{1}$ Detailed, for example, in the annual admissions report of the Registrar of the University of British Columbia to the University Senate.

${ }^{2}$ See Kieran Egan (1986), Teaching as Story Telling (London, ON: Althouse Press; London, UK: Routledge, 1989; Chicago: University of Chicago Press, 1989).

${ }^{3}$ Donald A. Schön (1987), Educating the Reflective Practitioner: Towards a New Design for Teaching and Learning in the Professions (San Francisco: Jossey-Boss).

${ }^{4}$ Richard Rorty (1980), "Pragmatism, Relativism, and Irrationalism," Proceedings and Addresses of the American Philosophical Association, 53, 727-728; quoted in Richard J. Bernstein (1983), Beyond Objectivism and Relativism: Science, Hermeneutics, and Praxis (Oxford: Blackwell), p. 201. 